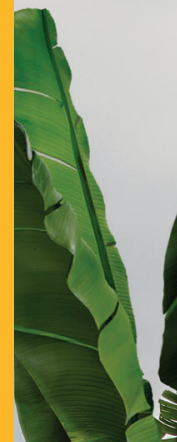

The Journal

\section{of the}

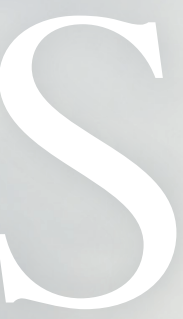

VOLUME 128 No.3 SEPTEMBER 2019

THE POLYNESIAN SOCIETY THE UNIVERSITY OF AUCKLAND NEW ZEALAND

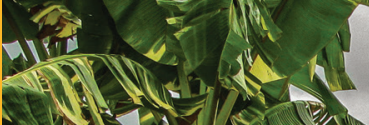

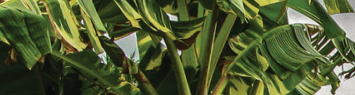

$3 x^{3}$

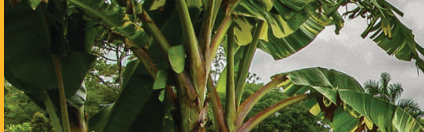

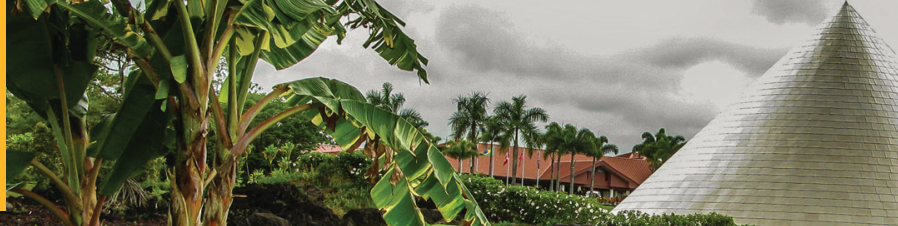

(6)

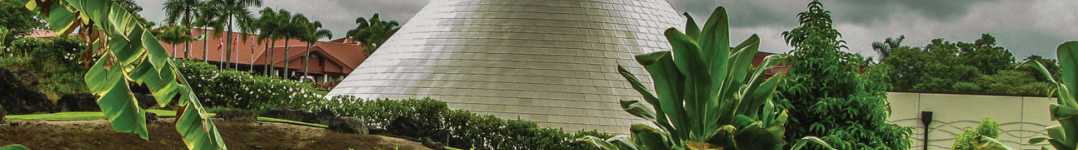

$1012(12)=0$

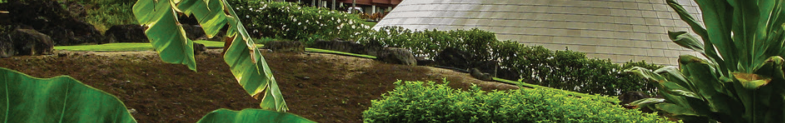

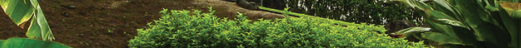

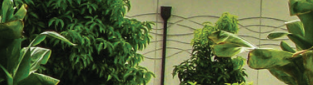

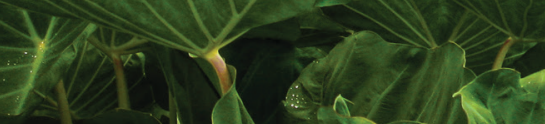




\title{
HAWAIIAN SEASCAPES AND LANDSCAPES: RECONSTRUCTING ELEMENTS OF A POLYNESIAN ECOLOGICAL KNOWLEDGE SYSTEM
}

\author{
BRIEN A. MEILLEUR \\ Laboratoire d'Éco-anthropologie \\ Muséum national d'Histoire naturelle
}

\begin{abstract}
Early western appreciations of the Hawaiian way of life in the late eighteenth and early nineteenth centuries suggested the pre-contact presence of highly structured regional chiefdoms and well-developed political economies founded upon elaborate knowledge of maritime and terrestrial environments. These first brief reports were substantiated and amplified in the mid- and late nineteenth-century published works of Native Hawaiian scholars who described a number of named landscape and seascape elements from which Hawaiians drew most of their subsistence base and material culture. Beginning in the 1950s, ethnologists, archaeologists and other investigators built upon these earlier accounts while studying Polynesian colonisation and occupation of Hawai' $i$. From the 1960s to the present, this research trajectory expanded into Hawaiian human ecology and political economy, refining former portraits of the subsistence strategies, environmental modifications and ecological knowledge employed by Hawaiians before Euro-American acculturative forces radically changed customary land-use patterns. Using an innovative theoretical framework recently proposed for ethnoecological research by Eugene Hunn and the author as the analytical backdrop, this paper will draw upon these sources, as well as new data from the Hawaiian Native Register of land claims (1846-1862) and unpublished contemporary reports, to evaluate aspects of traditional Hawaiian ecological knowledge as it may have existed to order and permit exploitation of late eighteenth- and early nineteenth-century marine and terrestrial environments.
\end{abstract}

Keywords: ethnoecological classification, Polynesia, traditional Hawaiian landscapes and seascapes, ecotopes

Recent re-evaluations of remote Eastern Polynesian radiocarbon dates place colonisation of Hawai' $i$ at around AD 1000-1100 by long-distance open-ocean voyagers from one of the central Polynesian archipelagos (Athens et al. 2014). ${ }^{1}$ In the late eighteenth and early nineteenth centuries the first European visitors found the approximately $17,000 \mathrm{~km}^{2}$ of the main Hawaiian Islands occupied by Polynesians practising a highly structured agricultural and piscicultural economy supplemented by natural-resource 
harvesting. The earliest written accounts of Hawai' $i$ revealed that production was organised within a socio-political-cosmological system dominated by chiefly religious classes.

While many features of traditional Hawaiian culture were overwhelmed during the nineteenth century by a developing Euro-American political economy, some older patterns of sea and land use appear to have remained relatively intact. By the 1830s many Hawaiians had gained literary skills and, concerned with the loss of their customary way of life, a number of prominent individuals throughout the nineteenth and early twentieth centuries produced important accounts of Hawaiian culture containing substantial detail of traditional ecological knowledge. First published mostly in Hawaiian-language newspapers, some of this literature has since been translated into English, and it is this body of work that began to reveal to the western world the sophistication of Hawaiian economic production and its grounding in elaborate bodies of environmental knowledge. At the same time, as the conversion to non-Hawaiian modes of ownership and production was underway, elements of traditional sea and land use continued to be recorded in government-sponsored land claim programmes and related boundary testimonies. Using a theoretical framework recently developed for ethnoecological research by Hunn and Meilleur (2010), this paper reconstructs indigenous Hawaiian ecological knowledge of marine and terrestrial environments as it may have existed between the late eighteenth and early twentieth centuries.

\section{METHODOLOGY}

The method employed for this analysis was to mine customary Hawaiian landuse and related terms and concepts from published, unpublished and archival documents and then to evaluate these within the landscape ethnoecological framework devised by Hunn and Meilleur (2010). They define a landscape ethnoecological classification as "a partition of a 'subsistence space' into patches, such that every point of that space will fall either within a patch or on the boundary between adjacent patches. ... These patches are tokens [referents] of types we prefer to call ecotopes" (p. 15). Ecotopic patches will generally map onto closed regions of the earth's surface, and their classifications will reflect more or less continuous patterns of variation among a range of partially independent dimensions, such as soil chemistry and plant associations. The possibility exists for a hierarchy of ecotopes.

The elements of the Hawaiian ecological knowledge system reconstructed here represent patterns that emerged from the reviewed documentary evidence, as they may have existed during the late traditional Hawaiian 
period. Key sources were the English-language works of several well-known nineteenth-century Hawaiian intellectuals, especially Kamakau ([1869-70] 1976), Kahā'ulelio ([1902] 2006), Kepelino in Beckwith ([1932] 2007), and Malo ([1898] 1903). Unpublished mid-nineteenth-century land claims and associated Boundary Commission testimonies (in Hawaiian and English) arising from the 1848 land redistribution and privatisation programme known as the Great Māhele were also used. These materials were complemented by the more recent Hawaiian Dictionary of Pukui and Elbert ([1957] 1986), by ethnographic and archaeological publications dealing largely with traditional land and resource use (e.g., Allen 2001; Allen and McAnany 1994; Fornander 1919a, 1919b; Handy 1940; Handy and Handy 1972; Handy and Pukui 1958; Holland 1971; Kelly 1983; Kikuchi 1973; Kirch 1985; Major 2001; McEldowney 1983; Newman 1970, 1971), and by unpublished contemporary culture-history reports for several islands and districts (Maly 1999; Maly and Maly 2001, 2002a, 2002b, 2003, 2005a, 2005b, 2006, 2012).

It is important to note that there are several weaknesses with the approach used here. For one, the data sources are exclusively literary and archival, and some of them are nearly 200 years old. Customary Hawaiian knowledge was not only passed down orally, it was often highly specialised and linked to family history and place of residence. Thus, written accounts of a small number of nineteenth-century Hawaiian intellectuals represent a snapshot of the diversity and complexity of cultural knowledge across the archipelago and its many varied landscapes as portrayed by a minimal set of culture-bearers over a short time period. Translating these compilations into English distances them even more from an ideal cultural authenticity. As I do not speak Hawaiian, I was obliged to work with English-language texts that had been translated from the original Hawaiian, sometimes several times (e.g., W.D. Alexander's “Introduction" to Malo's Hawaiian Antiquities [1903: 18]). Because of this, some Native Hawaiian scholars have advised caution and care in using English-language translations of Hawaiian texts in academic research (see e.g., Arista's "Foreword" in Kepelino's Traditions of Hawaii [Beckwith 2007]). Nonetheless, several of the most important of these sources were translated by Native Hawaiian speakers, foremost among these being Mary Kawena Pukui. While Pukui was undoubtedly familiar with most of the terms and concepts presented here, other translators, especially those of the nineteenth century, seemingly were not. Moreover, not all of the Hawaiian terms or concepts presented were identically translated, including those from the mid-nineteenth-century land claims and Boundary Commission testimonies, even when the translator was the same person. It is also clear that even Pukui was sometimes uncertain about the precise semantic 
content of some Hawaiian environmental terms as applied by the nineteenthcentury Hawaiian scholars. Lastly, this paper focuses almost exclusively on the practical economic implications of Hawaiian ethnoecological terms and concepts. In reality, Hawaiian subsistence space was permeated with spiritual and political content, the latter related especially to the traditional Hawaiian administrative land divisions (in descending order of size: moku, ahupua ' $a$, 'ili, mo'o, paukü), but no attempt has been made to weigh the degree to which these phenomena influenced the environmental patterning briefly reported here.

Hawaiians invested heavily both cognitively and linguistically in many domains of natural and anthropogenic environmental phenomena. While much intellectual focus was placed on types of heavenly bodies (with over 375 general terms and proper names recorded), aspects of weather (Malo 1903: 32-35; Pukui et al. 1974), and constructed space for shelter, religious practice, etc., this paper focuses almost entirely on the traditional oceanic and terrestrial knowledge that permitted Hawaiians to sustain a growing population and a complex, hierarchically organised society for nearly a thousand years.

\section{THE OCEANIC ENVIRONMENT}

Hawaiians related to the sea in many ways. They angled, netted, speared and trapped fish, octopus, crustaceans and turtles in the open ocean; gathered crustaceans, molluscs, turtles and algae on the shore; and raised, ensnared and gathered fish and other resources in littoral and inshore man-made saltwater ponds and traps. The emphasis placed on these resources varied over time and by place. They also enjoyed the sea for leisure and used it for interisland and coastal travel, and many of its features were prominent in Hawaiian songs, poetry, chants, tale-telling and cosmology (Finney 1959: 338-39; Kahā'ulelio 2006; Maly and Maly 2003: 162; Manu [1992] 2006; Titcomb 1952). Saltwater areas of the Hawaiian Islands were overlain by a dense conceptual grid of lexicalised traditional ecotopes, named places and oceanic forms and states. To give just two examples of oceanic nomenclatural elaboration, Pukui et al. (1974) identified over 1,700 surfing sites, most if not all marked by proper names. Similarly, many general terms and proper names were recorded by them and others for oceanic currents, straits and types of surf, tides and waves (Finney 1959; Kamakau 1976: 12-13; Malo 1903: 49), as well as for prominent geographic and topographic shoreline features. The Hawaiian terms for these features often show astonishing lexical complexity.

Where the sea cuts into the land in coves and bays, or where coral reefs or rocky flats or shoals were extensive, Hawaiians altered the natural coastline by fashioning saltwater ponds and traps using stone walls and sand embankments. Hundreds of these were constructed. Their formal and functional complexity 
allowed Hawaiians not only to exploit the geomorphological variation of island coastlines but also to diversify the oceanic resources gathered or captured there. Kikuchi (1973: 9-11), for example, recognised four principal types of saltwater ponds or traps, and several secondary ones, whose terms in Hawaiian could be modified according to form or function. While most of the saltwater ponds were relatively small, some of the larger ones covered several hundred hectares.

Saltwater ponds were designed to allow seawater to flow in at rising tide via channels or over their walls, thereby facilitating the acquisition of desirable species at ebb tide when capture was easier. Some saltwater ponds were located immediately coastward of the freshwater or brackish ponds described in more detail below. The two types (saltwater and freshwater) were distinguished by the different ecotopic zones in which they were located and their construction methods, associated species and distinct management principles.

As for the freshwater ponds (loko wai), the Hawaiian head term for pond, loko, was used with modifiers to differentiate saltwater pond types. For instance, loko kuāpa were made by constructing stone walls on a reef to create artificial enclosures. In contrast, loko pu'uone (or pu'uone) were constructed behind sand-dune ridges running more or less parallel to the coast, with seawater in- and outflow controlled by channels. Once the exterior walls or embankments of both types were completed, interior compartmentalisation might occur, permitting various methods of trapping different species and fish-farming, and such ponds $\left(k i^{\circ} \mathrm{o}\right)$ or pond enclosures $(p \bar{a})$ were labelled accordingly. The principal groups of species captured or gathered were saltwater fishes, crustaceans, turtles and algae (Kahā'ulelio 2006; Kikuchi 1973; Manu [1992] 2006; Titcomb 1972).

Complementing these humanised coastal ecotopes, the gathering of other saltwater resources (e.g., Field et al. 2016, Kirch 1985) was practised in natural oceanfront ecotopes. Shorelines or seacoasts (kapa kai) on the eight main islands vary in physical composition, shape, abruptness and species preferences, and resources ranged from salt to fishes, crustaceans, molluscs, turtles, algae and corals. Multiple terms exist for kinds of beach, sand, waves, swells or whitecaps, for reefs and shoals, and for a range of physical features that occurred at or near the water's edge. Hawaiians recognised many smaller-scale named ecotopes in this zone. For example, anchialine ponds or tidal pools ( $k \bar{a} h e k a$ : many kinds), sometimes used as temporary fishholding ponds (Kikuchi 1973: 10) or as salt-producing ponds ('alia: many kinds and lexical forms, natural and man-made), were common elements of the flatter shorelines. Where sandy beaches existed, crabs and turtles were obtained. Along shorelines strewn with smooth boulders ( $p a$ 'ala), limpets, crustaceans and seaweeds were gathered. Many hydrological-topographical features of irregular shorelines, like whirlpools, waterspouts and capes, were 
recognised using general terms, as were the straits between islands, with specific examples given proper names.

Even though human modifications lessened and progressively ended as one moved seaward from the shore, substantial bodies of traditional ecological knowledge at several conceptual levels were projected over, as well as under, the deepening ocean waters. Early appreciations of customary Hawaiian organisation of the oceanic environment are mostly based on descriptions provided by the nineteenth-century scholars Malo ([1898] 1903: 48-49), Kamakau ([1869-70] 1976) and Kahā'ulelio ([1902] 2006) with later additions and corrections provided by others, mostly Pukui in her many translations and publications. As we will see for the terrestrial environment, the Hawaiian maritime world was viewed generally as a series of ecotopes, at several levels of inclusion, which were depicted as a relatively steady progression from inshore to deeper waters with multiple "belts" or "parts" recognised. Indeed, a multitude of terms and concepts overlies both the inshore and deeper water zones, with these two sectors appearing to form an initial conceptual division of the maritime environment. As shown below, most of the Hawaiian oceanic categories were associated practically with resource acquisition, leisure activities and travel.

As one moved from the shoreline to inshore waters, generically referred to as kai papa ' $u$ [kai pappa 'u] 'shallow seas' by Kamakau (1976: 60), and then progressively out to the deeper ocean, generically indicated as kaiuli, kai uliuli or kai o' $o$ 'the deep blue sea' (see also Beckley 1883: 18), a sophisticated nomenclatural system employing well over 50 terms was applied to conceptualise and organise approximately 20 subdivisions of the ocean identified here as traditional maritime ecotopes. These were often translated as "belts", "parts", "places" or "areas" in the works of the Hawaiian intellectuals (Kamakau 1976: 11-12; Malo 1903: 48-49), who used expressions like "a little further out", "outside of this lay a belt" and "beyond this lies a belt", showing that the ocean (kai) at this level of abstraction was viewed more or less as a sequential series of zones each located progressively further from the shore.

The first detailed treatment of this pattern was produced by David Malo (Table 1). Born around 1793 and probably writing mostly in the 1830s, he was the first Hawaiian scholar to provide a meticulous account of the maritime environment. Samuel Kamakau presented the second important description of the Hawaiian oceanic environment. Born in 1815 and writing in the 1860s, Kamakau's Hawaiian-language texts were deemed by Dorothy Barrère (1976: v) to be "an amplification of Malo's earlier work". While much of Kamakau's scheme corresponds well with Malo's, the two formulations are not identical. Dissimilarities in detail exist, especially for the inshore sectors; he and later writers like Pukui defined some of Malo's terms for "belts" or oceanic zones differently, made corrections to them or added others. Generally, Kamakau's terms and phrases are more "analysable" than 
Malo's, that is, they employ more descriptive terms emphasising activities, ocean states or species associated with the labelled zones. His treatment of the open ocean is similar to Malo's.

Table 1. Malo's oceanic zones or "belts" (1903: 48-49) (approximate sequence, from the shore outwards).

\begin{tabular}{|c|c|}
\hline Hawaiian term & Description \\
\hline$a^{\prime} e-k a i[$ 'ae kai] & $\begin{array}{l}\text { "that strip of the beach over which the } \\
\text { waves ran after they had broken" }\end{array}$ \\
\hline pu-ao [pua'ō], ko-aka [ko'akā] & "that belt of shoal where the breakers curl" \\
\hline $\begin{array}{l}\text { poi'na-kai [po'ina kai] or pue-one [pu'e } \\
\text { one] }\end{array}$ & "a little further out where the waves break" \\
\hline kai-kohala $[$ kai kohala $]$ & "shoal water extended to a great distance" \\
\hline $\begin{array}{l}\text { kai-hele-ku [kai hele kū], kai-papau [kai } \\
\text { pāpa'u] or kai-ohua [kai 'ōhua] }\end{array}$ & "a belt ... water in which one could stand" \\
\hline kua-au $\left[k u a a^{\prime} a u\right]$ & "a belt ... where the shoal water ended" \\
\hline $\begin{array}{l}\text { kai-au [kai'au], ho-au [hō'au], kai-kohola } \\
\text { [kai kohola], kai-o-kilo-hee [kai'ókilo } \\
\text { he'e] or kai-hee-nalu [kai he'e nalu] }\end{array}$ & $\begin{array}{l}\text { "outside [of this ] a belt ... for swimming } \\
\text { deep ... for spearing squid [actually } \\
\text { octopus, Octopus spp.] ... a surf-swimming } \\
\text { region" [see Errata, p. 17] }\end{array}$ \\
\hline $\begin{array}{l}\text { kai-uli }[\text { kai uli }], \text { kai-lu-hee }[\text { kai lū he'e }] \text {, } \\
\text { kai-malolo }[\text { kai mālolo }] \text { or kai-opelu } \\
{[\text { kai 'opelu }]}\end{array}$ & $\begin{array}{l}\text { "outside } \ldots \text { was a belt } \ldots \text { blue sea } \ldots \text { the } \\
\text { squid-fishing sea ... sea-of-the flying-fish } \\
\text { [Parexocoetus brachypterus] sea ... or sea-of- }- \text {. } \\
\text { the opelu [mackerel scad, Decapterus spp.]" }\end{array}$ \\
\hline kai-hi-aku [kai hī aku] & $\begin{array}{l}\text { "beyond } \ldots \text { lies a belt } \ldots \text { sea for trolling } \\
\text { the aku [bonito, Katsuwonus pelamis]" }\end{array}$ \\
\hline kai-kohola [kai koholā $]$ & $\begin{array}{l}\text { "outside of this lay a belt ... where swim } \\
\text { the whales" }[\text { koholā, humpback whale, } \\
\text { Megaptera novaeangliae }]\end{array}$ \\
\hline $\begin{array}{l}\text { moana, waho-lilo [waho lilo], lepo, } \\
\text { lewa, lipo }\end{array}$ & "beyond this lay the deep ocean" \\
\hline Kahiki-moe [Kahiki moe] & "the utmost bounds of the ocean" \\
\hline
\end{tabular}


However, one significant difference was noted in Malo's scheme by Kamakau and others. When Malo (1903: 48) labels two zones kai-kohala, "where shoal water extended to a great distance" and then again "where the shoal water ended", his translator (Emerson) claims that this second use "is clearly a mistake ... [the actual term kohola being] applied only to the shoal water inside the surf" (Emerson in Malo 1903: 50, n6), much as Kamakau (1976: 11) and Pukui and Elbert describe it ([1957] 1986: 116, 159). Several minor differences also exist in translations by these latter authors. For instance in the Hawaiian Dictionary, pu 'e one is defined as "sand dune, sand bar" (1986: 348), in contrast to Malo's and Kamakau's zone where waves "break and spread toward the land". Beginning with the shallower zones, Pukui and Elbert (p. 168) also define kua 'au differently, as a "basin inside the reef; lagoon", while kai 'au is defined as "sea too deep to walk in" and kai he ' $e$ as "receding sea or wave" (p. 115). They also add ko "aka as "coral shoal" (p. 420), a term not found in the Malo or Kamakau schemes, though presumably occurring variously in this same shallow water zone. Pukui (in Titcomb 1972: 15) also defines "kilohe 'e grounds" as "the area shallow enough for wading, or examining the bottom from a canoe" and "lühe "e grounds" as "the area where the water was too deep for the bottom to be in sight", again somewhat differently than Malo and Kamakau, who emphasise octopus fishing in this zone. With the exception of moana, also defined by Pukui and Elbert (1986: 249) as "ocean, open sea", Malo's expressions for the "deep ocean belt"-waho-lilo, lepo, lewa and lipo - are not noted by Pukui and Elbert specifically as maritime terms. However, they state that lipo (and lepo) can be used as adjectives meaning "deep blue-black ... for the sea" (see also Kepelino in Beckwith 2007: 120, moana lipolipo, "the deep blue ocean"; and Kamakau 1976: 11).

Thus inconsistencies are found in the patterning and the semantic content presented by the two nineteenth-century Hawaiians as one moved seaward, and the boundaries described are imprecise based on a reading of this literature. Nevertheless, each zone or "belt" was associated variously (by these and later Hawaiian scholars) with increasing distance from the shore, water depth, and sometimes the shape of waves or the ocean floor and the current flow that occurred there. The sort of human activity and especially the resources that were captured there were also important. Capture methods ranged from angling to spearing to netting and trapping, even poisoning (Cobb 1903: 735; Fornander 1919b, vol. 6: 174-88; Kahā'ulelio 2006: 53), with different strategies often associated with each "belt". Bathing, surfing and ocean travel also occurred in these ecotopes.

The principal terms and their modifiers associated with the open-ocean belts thus shifted from a perception of the readily visible elements of the nearshore to those aspects of the sea linked to distance from land and to the species likely to occur in each belt and at different depths, with differences in wave 
forms, currents or colours associated with each belt, and with irregularities of the sea floor (papakī) such as crevices (naele), natural caverns (e.g., 'a 'aka, lua) and holes or man-made stone cairns (ahu, 'āhua pōhaku, imu, $u m u$ ). While some species occurred widely, others had narrower distributions. Traditional knowledge associated with these belts and their oceanic features was employed to predict resource presence, determine desirable spots for leisure, and/or as aids or hindrances in open-ocean travel. Some, like the shape or colour of waves or the strength of tides or swells, were useful in predicting weather or events like undersea volcanic eruptions or tsunamis.

However, an awareness of the land, especially when heading toward preferred fishing areas (kai lawai 'a), was always present. For example, when approaching an appropriate belt in search of a desired species, the exact fishing station (ko'a, ko'a i'a, ko'a-lawaia [ko'a lawai'a], also äukauka) might be located by a method that aligned two or more prominent land features from one or more islands (Cobb 1903: 738; Fornander 1919b, vol. 6: 186; Kahā'ulelio 2006: 43; Malo 1903: 278). In some instances this involved the use of landmarks at considerable distances from the shore. According to Kamakau (1976: 78) the fishing grounds specifically located by the use of landmarks were called kиари'e or ko 'a kиари'e.

Terrestrial points of reference at several elevations were employed to locate many of the more distant offshore fishing stations, since fog or clouds could hide any of the landmarks at any time. Once the station was reached by triangulating these points, in effect by a Hawaiian version of fixing latitude and longitude, a cavern, hole or other seafloor feature known to host a particular resource could be found. If hook and line were used to catch a species known to prefer a certain water depth, distance from the surface was determined with a marked, weighted line. Such fishing stations were thus located using a three-dimensional calculation. The landmarks furnished the reference points on a two-dimensional horizontal axis, while depth, the vertical axis, was determined by the line. Each preferred station was unique and labelled by a proper name, even though most were invisible - that is, they had never actually been seen or visited below the ocean's surface.

In addition to the individual fishing stations, which were often kept as family secrets, four or five deeper-water ecotopic zones seem to have been recognised and named generically. According to Kamakau (1976: 75), deep-sea fishing areas were called ko 'a hohonu, while those located at "eighty fathoms more or less" (around $146 \mathrm{~m}$ ) were named kükaula (see also Kahā'ulelio 2006: 131). Deeper still, the zone preferred by kāhala fish (amberjack or yellowtail, Seriola dumerilii) and 'ahi (yellowfin tuna, Thunnus albacares) was called $\mathrm{ka}$ ' $a \mathrm{ka}$ ' $a$, and the deepest ecotope of all, "two or three hundred fathoms deep [366-549 m] and even up to four hundred [732 m]", ${ }^{3}$ was called pōhäkialoa (possibly also kialoa or kaka [kākā]) 
(Kamakau 1976: 90, fn14). The Kamakau text suggests that several of these terms could be applied polysemously, both to the deeper water ecotopes and to the techniques employed in capturing their desired resources.

Over time, Hawaiians had thus discovered, cognitively mapped and named many of the most productive resource acquisition areas in their offshore waters. These were perceptually organised and located through a discovery process involving at least five levels of environmental conceptualisation. The broadest or most inclusive level, the undifferentiated sea (kai), was subdivided first into inshore versus offshore waters. These then were divided into around 20 customary ecotopic belts at various distances from the land, sometimes at considerable depths, that I will call broader-scale ecotopes. Each of these was variably composed of smaller-scale surface and/or underwater ecotopes at a fourth level of abstraction. This latter group of Hawaiian ecotopes, which are essentially habitats, constituted a range of water layers or zones located at different depths, current confluences, or sea floor sites that were known to be preferred by different species generally and/ or at certain times of the day or year (Titcomb 1972). Categories at these latter two conceptual levels were labelled generically with common terms, as they could conceivably exist in the offshore waters of any island, although, like offshore fishing in the Society Islands (Nordhoff 1930: 150) and at Tobi Island in Palau (Johannes 1981: 101), windward and leeward differences and seabottom and current-flow variation undoubtedly conditioned their presence within the archipelago. Evidence suggests that the three broader-scale ecotopic types - the ocean itself, the inshore-offshore distinction, the 20 or so surface and subsurface "belts"-were more general-purpose categories, while the smaller-scale ecotopes were more special-purpose, though this distinction was not always clear. For example, many fishing stations ( $k o$ ' $a$ ) widespread in offshore waters could be labelled by addition of descriptive modifiers, thus in effect designating predictable zones of presence for desired species, as, for example, ko 'a-ahi [ko'a 'ahi], place where yellowfin tuna could be found, or ko 'a aku, place for bonito (Malo 1903: 278). The specific fishing station itself that was regularly used by an individual fisherman constituted a fifth level of abstraction. These were unique places with the most limited spatial extent, either occurring within the larger-scale "belts" or as exemplars of the smaller-scale ecotopes, and all of these were labelled with proper names. The Hawaiian fisherman Kahā'ulelio, born in 1835 in Wailehua, Lahaina, Maui, knew over 100 of these deep-sea fishing sites, each labelled by a proper name (Kahā'ulelio 2006: 55; see Nordhoff 1930: 143 for similarities with early twentieth-century Tahiti).

By developing skills in identifying and classifying their saltwater environment at five levels of abstraction, and by combining this expertise with 
the recognition, naming and classification of many oceanic species and an extensive knowledge of their behaviour, Hawaiians were consistently able to locate unique places in the ocean. Importantly this system allowed them to capture associated resources, sometimes at substantial distances from the land and at great depths. When considering the deeper-water resource-acquisition strategies, along with Hawaiian saltwater pisciculture and inshore fishing and gathering with the many forms of agriculture and natural-resource gathering on land described below, one gains an appreciation of the exceptional nature of the Polynesian adaptation to one of the most remote island archipelagos in the world. As we will see, the ecotopic patterning on land is similar to that developed by Hawaiians for the sea.

\section{THE TERRESTRIAL ENVIRONMENT}

As for their oceanic world, the nineteenth-century Hawaiian writers conceptualised their terrestrial landscapes at several levels of abstraction. The first conceptual level is that of the Hawaiian Islands themselves $(k \bar{o}$ Hawai 'i pae 'äina), with each of the eight main islands attributed a proper name. This nomenclature recognising uniqueness is complemented by a set of generic referential terms such as island (moku, mokupuni, moku'äina, $m \bar{o}$ ) and another set of terms distinguishing geomorphological types of islands: submerged, low-reef island, islet, many islets, double island, atoll, etc. (Kamakau 1976: 7; Pukui and Elbert 1986). A third level of abstraction organised all the land on each of the main islands into a dozen or so broaderscale, named ecotopic zones. While some variation exists in the description of these zones, often also called "belts" in the nineteenth-century Hawaiian literature, they are portrayed by the early Hawaiian writers as a series of partitions that succeed each other in descending order from the mountains to the sea. Though their limits and even their presence undoubtedly varied from one island and district to another, their conceptual similarity with the oceanic belts is striking. Evidence suggests that each of these terrestrial zones was perceived by nineteenth-century Hawaiians as a combination of physiognomic, biotic, hydrologic and geologic-edaphic elements, as well as by the human activities (and cosmological beliefs and politicaladministrative subdivisions) associated with it. A fourth level of terrestrial conceptualisation occurred at a smaller scale. Here, Hawaiians recognised a set of what might be called "classic" ecotopes or landscape patches. Also, zonation here was more random, though the ecotopes at this level could occur with some predictability within one or another of the broader-scale "belts". As for the oceanic ecotopes at the third level of abstraction, their specific tokens or exemplars had substantially narrower spatial ranges. Hawaiian conceptualisation of the terrestrial environment is examined below. 
Hawaiian Patterns of the Terrestrial Landscape

Like for the oceanic world, our understanding of how Hawaiians conceptualised their terrestrial landscapes is derived mainly from nineteenth-century descriptions by Hawaiian intellectuals and from mid-nineteenth-century landuse records, and secondarily from interpretations of these sources in more recent historical, ethnographical and archaeological accounts. The Hawaiian writers most likely furnished firsthand or near-firsthand descriptions of their terrestrial environments, identifying about a dozen broader-scale environmental "belts" or zones that were distributed more or less predictably over the land. These were depicted as beginning at the highest points on the main islands and succeeding each other sequentially as they descended to the sea.

The highest elevation zones were reflected in Hawaiian knowledge of mountain-tops, peaks, volcanic craters and high-altitude ridges (Malo 1903: 37; Pukui and Elbert 1986: 168). Mostly residing in the botanists' alpine zone (Wagner et al. 1990) occurring only on Hawai'i Island, the highest zone, called kua-lono [kualono] by Malo (1903: 37), referred to "the peaks or ridges which form [the mountain] summits" while collectively "the mountains in [an island's] centre" are called kua-hiwi [kuahiwi]. Both areas were infrequently visited by Hawaiians, except periodically for burials or trips by specialists to preferred stone quarries. "Below the kua-hiwi comes a belt adjoining the rounded swell of the mountain called kua-mauna [kuamauna] or mauna, the mountainside" (p. 37). Again, according to Malo, the first belt to have biotic content, called kua-hea [kuahea], occurs immediately below or seaward (makai) from the highest elevation belts; this was where "small trees grow". ${ }^{4}$ Continuing downslope, this zone is followed by the wao, waonahele [wao nahele] or wao-eiwa [wao 'eiwa] "belt ... where the larger ... forest-trees grow" (p. 37; but on p. 41 Malo defines nahele or nahele-hele [nāhelehele] as "small growths [such] as brush, shrubs, and chaparral"). Wao-eiwa is succeeded by the wao-maukele [wao ma'u kele], where "the monarchs of the forest grew" (probably mostly koa [Acacia koa]) (p. 38; see also Fornander 1919a, vol. 5: 615) who calls "wao kele ... tall forests" but also the place where maile [Alyxia olivaeformis] grows; and Pukui and Elbert 1986: 382, who define wao kele as "rain belt, upland forest"). The wao-akua [wao akua] belt comes next, "in which again trees of smaller size grew" (Malo 1903: 38). This zone is followed by the wao-kanaka [wao kanaka] or mau [ma' $u$ ] belt, where "grows the am'au ['ama' $u$ ] fern [Sadleria spp.] and [where] men cultivate the land". Continuing downslope, one enters the "hard, baked, sterile" apaa ['apa'a] belt, seemingly once dominated by grass, possibly by pili (Heteropogon contortus). Now well into areas of human habitation and dense economic activity, the 'apa ' $a$ is succeeded by ilima ['ilima], a belt presumably dominated by 'ilima (Sida fallax) (without explanation, Pukui and Elbert 1986: 28 claim equivalency between 'apa' $a$ and wao 'ilima). Below 'ilima is the pahee [pahe' $e$ ] belt, 
translated in English as "slippery" (Pukui and Elbert 1986: 299), possibly by reference to an unidentified grass that was said to occur there (Malo 1903: 39, n8). Below pahe' $e$ comes the kula belt or "plain, open country ... near to the habitations of men" and which undoubtedly represented the dominant terrestrial zone on all the islands. After kula comes kahakai, "the belt bordering the ocean" (p. 38).

As for the oceanic environment, Kamakau modified Malo's scheme by naming several "belts" differently, defining some terms differently, recognising additional named zones and somewhat changing Malo's order of zones as they descended to the sea. For example, he states that the "kuahiwi proper" (Malo's high mountain ridge belt) occurred below Malo's kuahea zone, and he recognised a wao-lipo [wao lipo] zone between Malo's wao-nahele or wao-eiwa, and which he separated into two belts. He also added wao la 'au [wao lā' 'au] as a wide-ranging zone of "timber land ... dry forest growths from the "apa 'a up to the kuahiwi" (Kamakau 1976: 9). Moreover, he recognised a distinct " "ama ' $u$ fern belt" (also called amaumau ['ama 'uma 'u] in Maly and Maly 2002b: 147-48; partial repetition indicating a concentration of ferns; see a similar pattern for "mud" below). This latter zone occurred below Malo's wao-kanaka belt.

While it is difficult today to assess fully the significance of these revisions, in reality the two schemes are quite similar. It may be important to note that Kamakau, who was born on O'ahu's north shore but moved as a young man to Lahaina, Maui, only to return in later life to O'ahu, may actually have refined Malo's pattern based on his seemingly more extensive travel within the Hawaiian Islands. For instance, he added a dry forest zone (wao la 'au) that is lacking in Malo's rendition. Pukui and Elbert define the wao lā 'au more loosely as the "same as wao nahele ... or inland forest region, jungle, desert" (1986: 382) and they translate $l \bar{a}$ ' $a u$ in this context as "forest ... thicket" (p. 188). The term nahele is found in many mo 'olelo (Hawaiian stories) and other accounts in the Fornander collection where it is mostly employed generically, usually translated simply as "woods". In Kepelino's Traditions of Hawaii, Beckwith defines the term as "underbrush" (2007: 118) and even as "weeds" (p. 152). In a prayer cited by Kamakau (1976: 137), designed to aid timber-seekers in house construction, kele and ma "ukele are translated by Pukui as "rain forest" and wao koa as "koa forest".

While the Malo and Kamakau schemes represent our core understanding of customary broader-scale Hawaiian landscape conceptualisation, several revisions were later made to their schemes that are now accepted by most informed observers. This process began in 1940 when the ethnologist E.S. Craighill Handy reprised the notion of traditional Hawaiian terrestrial zonation in his study (Handy 1940) of customary land use in Kona, Hawai' $i$ Island. But instead of framing his analysis in terms used by the earlier Hawaiian writers, he employed terms like "upland plantations" 
(pp. 47, 197), "forest zone" (pp. 9, 147), "fern-forest zone" (p. 52) and "intermediate zone" (p. 116). While he referred at least once to the wao akua ("jungle of the gods", p. 46), he surprisingly described only the kula zone (pp. 52, 59, 64, etc.) as a native environmental concept. However, a major change occurred in his 1958 volume The Polynesian Family System in Ka' $u$, Hawai ' $i$, co-authored with Mary Kawena Pukui (and see Handy and Handy 1972: 554-56). Here they present a more detailed assessment of the broader-scale Hawaiian landscape terms and concepts as found in Ka'u, Hawai'i Island, where Pukui was born and raised. Their map (p. 19) somewhat modified the order of the "belts" described by the earlier Hawaiian writers, and they split the kula into two zones (kula uka 'upland slopes' and kula kai 'lowest habitable zone'). The Hawaiian terms also were sometimes defined differently in English than in the Malo and Kamakau accounts. Nevertheless, their interpretation recognised, in descending order, eight customary environmental "zones" ranging from the mountain top (piko) to the shore (kahakai). Though supposition, these small differences from the earlier accounts may have resulted from different objectives, the nineteenth-century intellectuals perhaps producing idealised landscape patterns capable of capturing a wider range of terrestrial zones, while the goal of Handy and Pukui was probably to portray a traditional environmental arrangement as it existed in Ka' $u$ within a much smaller geographical area. The Handy and Pukui account also differed from the earlier schemes in that it identified more of the dominant wild and crop plants associated with each zone as well as the human activities practised there. It also recognised that the Ka'u zones were "not fixed as to altitude" (p. 21) and that they "gradually merge" into each other rather than having distinct boundaries - issues that the nineteenth-century accounts did not address.

\section{"Discovery" of a Kaluulu Zone in West Hawai ' $i$}

In her 1983 report Nã Māla O Kona on the agricultural history of Kona, Hawai'i Island, Marion Kelly drew more heavily from the Hawaiian environmental zonation schemes of Malo and Kamakau to interpret her archival research on the 1848 West Hawai'i Māhele land claims. Because the translators of these records were unaware of English equivalencies for some Hawaiian words, numerous Hawaiian terms occur within the Englishlanguage texts, including several for the broader-scale terrestrial zones portrayed by Malo and Kamakau. Kelly found references in the land claim records not only to the kula but also to the 'apa' $a$ and the 'ama' $u$ zones, thereby affirming the validity of the Malo and Kamakau schemes. Moreover, Kelly "discovered" a possible "new" Hawaiian ecotopic zone, the kaulu, kaluulu or $u l u$ that was placed by property claimants between the kula and the 'apa' $a$ zones. While uncertainty remains as to the exact meaning and/ or landscape referent for these terms, in part because they were written in 
the mid-nineteenth century in several ways, but also because $u l u$ without the glottal stop has been defined as "grove" in English, and because kaulu has been lexically glossed to several native tree species and places (Pukui and Elbert 1986: 137), Kelly's contention that kaluulu likely refers to a vegetation zone dominated by breadfruit ('ulu) is a reasonable and now generally accepted conclusion. A massive pre-Euro-American upland area of intensive breadfruit arboriculture above Kealakekua Bay is now well substantiated (Allen 2004: 191, 216-20; Kelly 1983; Lincoln and Ladefoged 2014; Meilleur et al. 2004).

It would be difficult today to establish equivalencies between the broaderscale Hawaiian landscape belts and contemporary ecological concepts such as physiognomic zones or vegetation communities, though modest attempts have been made (Mueller-Dombois 2007: 24-27). Nevertheless, despite their dimensional and definitional imprecision, the Hawaiian landscape belts provide a valuable rendition of at least one traditional knowledge pattern that was undoubtedly employed by Hawaiians in the mid-nineteenth century to conceptualise major elements of their terrestrial environment. More recently, some aspects of the agriculture-dominated belts first raised by Handy and Pukui (1958) - their associated crop plants and their spatial intergradationhave been reprised by several authors working mostly on the distribution and intensity of Hawaiian dryland agriculture in relation to environmental variables in Kona, Hawai' $i$ Island (Allen 2004; Lincoln et al. 2014; Lincoln and Vitousek 2017). Nevertheless, when emphasising traditional Hawaiian landscape conceptualisation and the relation between ecotopes and their defining features, it is important to note that their associated plant and animal (Hawaiian folk taxa) and geologic-edaphic elements (see below) were not always resources, since agricultural pests and weeds might also occur there (Malo 1903: 270).

Smaller-scale ecotopic patterning of the terrestrial environment also occurred, with most of the exemplars of these categories located within one or more of the broader-scale zones presented above. These are typified by narrower biotic and/or physical content; in fact, in the older Hawaiian texts they are often associated with a single dominant plant species, physical element or function. I begin by examining several of the better-known Hawaiian biotic assemblages.

\section{The Terrestrial Biotic Ecotopes ${ }^{5}$}

Many Hawaiian terms applied to terrestrial environments designate ecotopic patches dominated by one or more of the plant (or animal) taxa that predictably occurred there. The semantic content of such terms thus reflects not only an awareness of specific vegetation formations or densities, whether wild or domesticated, but also implicitly the activities that occurred there, usually wild plant gathering or farming. 
"Natural" Hawaiian Terrestrial Ecotopes. Though Hawaiian subsistence was overwhelmingly grounded in farming, fish-farming and fishing, and productive emphasis varied by island and district and over time, wild plants and animals were also gathered and/or tended to satisfy dietary and medicinal needs and other uses ranging from house and canoe building to domestic, decorative and religious applications. Hawaiians knew of course where to obtain these plants and animals in the ecotopes in which they occurred. While other natural environmental components were also often associated with the terrestrial ecotopes, like soil qualities or hydrographic features, some appear to be most closely associated conceptually with a single or a small number of biotic elements. This is reflected in a pattern of polysemy that can be found for both the broader- and smaller-scale terrestrial ecotopes. Indeed, many Hawaiian terms for important wild plants appear to mark not only the plants themselves but also the ecotopic patches where concentrations of these plants occurred. This phenomenon is found for at least three of the broader-scale Hawaiian ecotopic zones - the 'ilima belt ('ilima, Sida fallax), the ma' $u$ or 'ama' $u$ belt (Sadleria spp.) and the kaulu, kaluulu or ulu zone ('ulu, breadfruit, Artocarpus altilis). This conclusion is confirmed by Pukui who glossed the term 'ilima both to the Sida fallax plant and to the "area where "ilima plants may grow" (Pukui and Elbert 1986: 98). The same is true for 'ama' $u$, which she defines both as the Sadleria tree fern and as the "place where 'ama ' $u$ ferns are found" (p. 23). Hawaiian land and resource claims and Boundary Commission testimonies suggest that this phenomenon also occurred at a narrower spatial scale for many other well-known plant species and for the smaller-scale Hawaiian ecotopes in which they commonly occurred. Polysemy seems to be true for: hāpu'u (Cibotium splendens) and olona (Touchardia latifolia), found in wetter areas of the 'ama' $u$ and wao belts; pili (Heteropogon contortus) (McEldowney 1983: 415), once common in the kula and probably the 'apa 'a belts; mämane (Sophora chrysophylla), common in the drier upland zones and possibly in the pahe ' $e$ belt; 'ie or 'ie 'ie (Freycinetia arborea), common in the lower wao belts; 'aka 'akai (Scirpus validus), encountered on the edges of freshwater ponds; possibly also pappala (Charpentiera spp.), found in upland $\mathrm{Ka}^{6} \mathrm{u}$, Hawai' $\mathrm{i}$ Island (E. Handy in Handy and Pukui 1958: 217-18); and for several other species and their associated smaller-scale ecotopic patches.

A second lexicographic and cognitive pattern that seems to have existed in Hawaiian environmental classification at this narrower level of abstraction applies to patches of mixed wood or forest species. In the absence of metal, stone and wood took on great importance, and areas where desirable woody species were concentrated were named accordingly. The Hawaiian literature and archival records reveal what appear to be several binomially labelled ecotopes that are dominated by woody species, where the head term for forest, wood or thicket $(l \bar{a} ' a u)$ or grove $(m \bar{o}, m o k u, u l u)$ is followed by the 
name of the species in question. Among the many examples found are the expressions ulu hala (pandanus grove), ulu niu (coconut grove) and ulu kou (Cordia subcordata grove). The whereabouts of these woody patches or groves were widely known and shared, as for the polysemously defined smaller-scale ecotopes, and all of them seem to have occurred within one or more of the broader-scale Hawaiian ecotopic belts already described. Finally, and perhaps in part because of the continual need for indeterminate wood and brush species for fuel, several Hawaiian terms that are more general-purpose mark ecotopic concepts such as woody or brushy thickets ( $\bar{p} p \bar{u}$ nāhelehele, puo 'a, ulueki).

Other general-purpose terms for ecotopes seem to have been applied by Hawaiians to natural biotic and physical phenomena for use primarily in spatial reckoning. Foremost among these are terms marking concepts of contiguity or proximity such as edges or clearings associated with dense vegetational formations. For example, pili lā 'au is defined by Pukui and Elbert as "edge of a forest" (1986: 330), while 'okipu ' $u$ is marked as "forest clearing" (p. 282). Both terms appear regularly in Boundary Commission testimonies on $\mathrm{O}^{\prime}$ ahu in the nineteenth century (Maly and Maly 2012: 519). Notions for edges or borders are even more widely applied by Hawaiians in the anthropogenic landscapes associated with farming and pisciculture, as discussed below.

Anthropogenic Terrestrial Ecotopes. Hawaiians modified significant areas of their terrestrial environment for economic purposes. ${ }^{6}$ Natural vegetation was cleared for agriculture via burning. Also, various forms of earth and rock movement were undertaken, including wall and mound building; the alteration of river mouths, floodplains and nearby valley walls via terracing; the creation of irrigation systems drawing water from freshwater streams; and incising of hillsides to reach the water table (Kirch 1977). Natural animal (especially bird) communities were also altered by gathering, hunting or trapping, as were wild-tended and domesticated plant species via transplanting for easier access. Freshwater ponds were created for taro cultivation and for pisciculture. These were fed and drained by inflow and outflow channels, and domesticated and semi-domesticated plants were often established on their walls and edges. Hawaiians might dam or otherwise modify freshwater streams to facilitate fishing and gathering crustaceans, and some upland areas were modified for stone quarrying.

Cultivated lands ranged from small house gardens or individual plots, both near and at some distance from coastal and/or upland habitations, to the hundreds of small to large irrigated ponds and massive dryland field systems controlled by chiefs and cultivated primarily by Hawaiian commoners. The recent summaries by Noa Lincoln and Peter Vitousek (2017) and by Ladefoged et al. (2018) of Hawaiian cultivated landscapes and their relation to island age, soils, climate and/or water availability, steepness and elevation, and their evolution after Polynesian arrival, show the extent to which the 
understanding of Hawaiian agricultural diversity has come since Newman's analysis (1971) of missionary William Ellis's trip around Hawai'i Island in 1823. All the major crops - taro (kalo), sweet potato ('uala), banana (mai'a), breadfruit ('ulu), sugar cane $(k \bar{o})$ and yam (uhi) - were cultivated in many settings. Secondary foods like coconut (niu), bottle gourd (ipu, Lagenaria siceraria) and arrow root (pia, Tacca leontopetaloides) were grown in appropriate habitats, as were paper mulberry (wauke, Broussonetia papyrifera), the Hawaiian cloth plant, and 'awa (kava, Piper methysticum), the lightly psychoactive central nervous system depressant commonly consumed in liquid form. A diversified dryland farming pattern (Lincoln et al. 2014; Lincoln and Vitousek 2017) ranged from massive field systems to colluvial slope cultivation to cleared forest settings to small mounded or isolated lavadominated patches (e.g., ala 'alai or kipi 'type of taro patch'; kippohopoho 'small arable patch surrounded by lava beds', Pukui and Elbert 1986: 17, 155; Figs 1 and 2). Dryland farming was complemented by substantial and wellorganised irrigated taro-pond farming, largely in windward areas (Kirch 1977, 2010; McIvor and Ladefoged 2018). Kamakau (1976: 31) makes an important linguistic and conceptual distinction between "dry" lands (aina malo 'o) and "wet" lands ( 'aina wai), especially in agricultural contexts (see also Fornander 1919b, vol. 6: 160; Kepelino in Beckwith 2007: 152-54; Malo 1903: 269). Many economically important near-crops like kou (Cordia subcordata), olonā, $k \bar{\imath}$ (ti, Cordyline fruticosa), hala (screwpine, Pandanus tectorius) and loulu (Pritchardia spp.) were regularly tended and/or transplanted to more convenient locations for easier access.

At least a dozen Hawaiian terms have been glossed by authorities to garden and/or to cultivated plot, patch or field (kaikā, kīhäpai, kula, mahi, māla, waena, etc.), and these terms are regularly cited in Māhele land claims. The terms marking what appear to be the same or similar concepts beg the question of the degree of functional equivalency among them and/or the extent of synonymy within the archipelago, since islands and/or districts had developed distinct lexicons for environmental and other phenomena (Kamakau 1976: 3-5). While Dorothy Barrère (pers. comm., n.d.) considered kīhāpai and māla to be "interchangeable" referents for "garden", the two terms are sometimes cited in the same claim, suggesting the possibility of functional differences, and some authors have defined them differently. Handy (1940), for example, defines kīhäpai as "garden patches" (p. 49), "dry land farms" (p. 51), "upland planting grounds" (p. 196), "abandoned inland homesteads" (p. 198) and "old garden plots" (p. 199), while the term is also found in Māhele claims for irrigated terrace ponds (lo ‘i) (Maly and Maly 2002b: 276-77). Kamakau (1976: 28-29) seems to make a distinction between kīhāpai ("garden") and waena ("field or cultivated area") in several of his kāhea planting chants, suggesting a conceptual distinction based on plot location or size. Handy (1940: 47), quoting the planter Kalokuokamaile, defines waena 


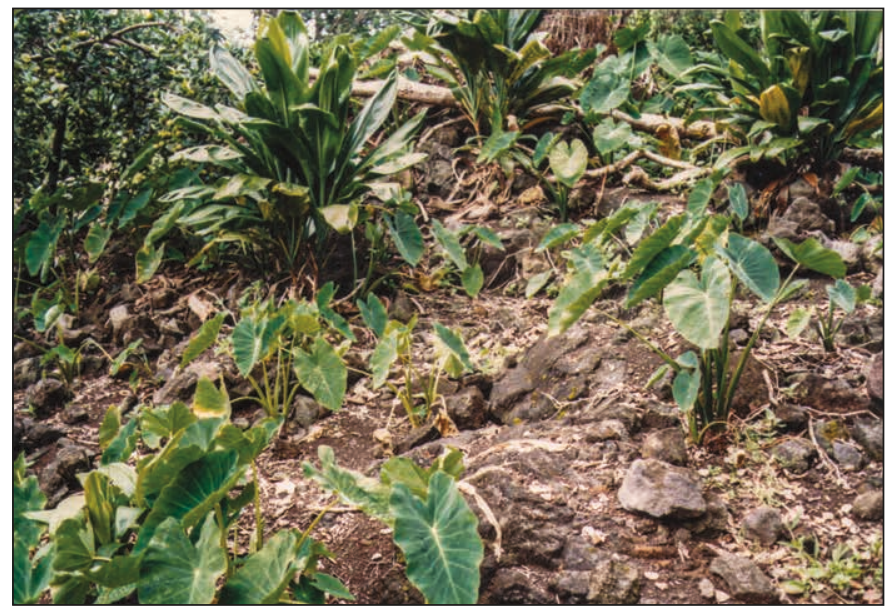

Figure 1. Lehua-type cultivar of taro (kalo, Colocasia esculenta) and ti (kī, Cordyline fruticosa) cultivated in an old lava flow at about $500 \mathrm{~m}$ elevation, 'Ōlelomoana Ahupua'a, South Kona, Hawai'i Island. Author's photo, 7 November 1987.

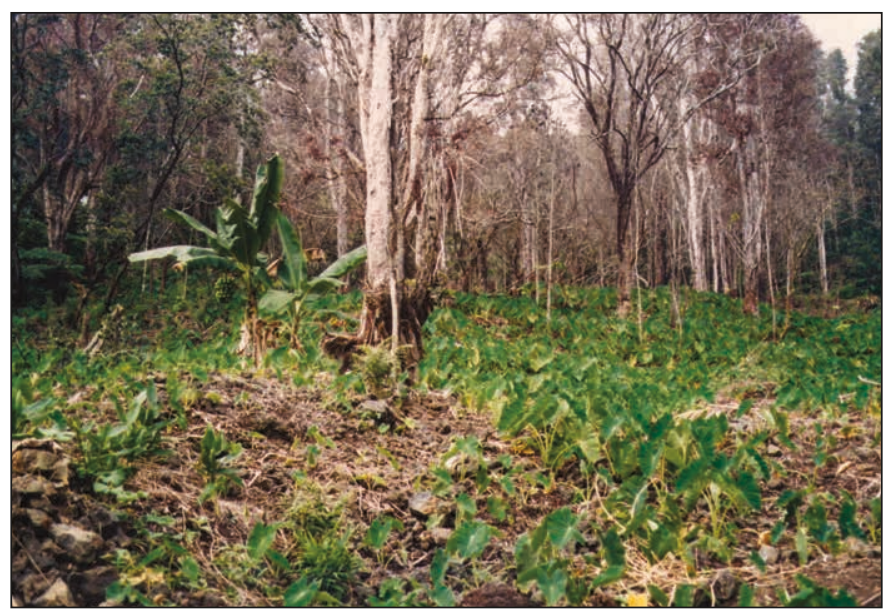

Figure 2. Lehua-type cultivar of taro (kalo, Colocasia esculenta) and maoli-type banana (mai'a, Musa sp.) cultivated in older 'ōhi'a lehua (Metrosideros polymorpha)_-dominated lava flow at about $500 \mathrm{~m}$ elevation, 'Ōlelomoana Ahupua‘a, South Kona, Hawai'i Island. Author's photo, 7 November 1987. 
as "upland plantations in clearings in the forest zone". Some of these terms are encountered in binomial form in land claims where the head term is followed by a plant modifier (māla kalo, māla 'uala, māla mai 'a, and even for wild plants, e.g., kīhāpai 'ie and kīhāpai olonā) (Maly and Maly 2002b: 115, 285-86) indicating that taro, sweet potato, banana, Freycenitia arborea and Touchardia latifolia were being grown (or tended) in the claimed plots. Many of the smaller cultivated parcels were located in or close to the once well-developed dryland field systems, while others were located further away, in valleys or gulches (kahawai) (see colluvial slope agriculture below), in holes in lava fields and at the limit of or in openings in the natural upland forest.

In some cases claimants specified in which of the broader-scale "belts" their gardens or plots were located, thereby recognising an element of scale between the two ecotopic levels introduced above, as predicted by Hunn and Meilleur (2010). This is evident when considering claims like "4 mala are in [the] ulu" "3 mala of sweet potatoes are in the kula", "6 [are] in the apaa" or "1 [is] in the amau fern zone" (LCA 7745, Keohoaeae, Maigret n.d.).

Anomalous terms denoting arable patches were found, and it is uncertain where their exemplars were physically located within the traditional Hawaiian agricultural scheme (e.g., as presented by Lincoln and Vitousek 2017). For instance, it is unclear where makaili, kippohopoho or kippohopoho makaili might have been found, though these presumed ecotopes are often linked to taro and sweet potato cultivation in or near rocky places and lava beds (Fornander 1919b, vol. 6: 164; Handy 1940: 51; Kamakau 1976: 40; Pukui and Elbert 1986: 155, 226). The same applies to 'aina palawai or palawai, glossed as "bottom lands ... where sweet potato and sugar cane were planted [and which often] flooded" (Kamakau 1976: 23-25; see also Pukui and Elbert 1986: 311). None of these presumed smaller-scale Hawaiian ecotopes are cited in Malo or in the customary Ka'u land configuration described by Handy and Pukui. The first group of terms seems to refer to small cultivated patches, probably mulched, within lava-dominated areas with little topsoil, possibly located within the kula belt. The latter terms may refer to some sort of fertile, lowlying area (river valley floodplain?) that regularly flooded and was burned before planting, perhaps within either the kahakai or kula belts. It is possible that some of the smaller-scale cultivated ecotopes associated with dryland taro or sweet potato, involving planting mounds ( $p u^{\prime} e$, Kamakau 1976: 26; Pukui and Elbert 1986: 348; or puepue [ри'ери 'e], Handy 1940: 12; Maly and Maly 2002b: 131), and once located in lava-dominated or sandy areas, were no longer being cultivated by the mid-nineteenth century following Hawaiian population collapse from introduced diseases (Ladefoged et al. 2009: 2376; Vitousek et al. 2004: 1666). As a result, the physical tokens for some of these Hawaiian terms may have become ambiguous or lost by the time the early Hawaiian scholars were writing, even where terms existed (see 
Barrère 1976: v). Recent archaeology and land-use modelling in Hawai'i have recognised the importance of rain-fed agriculture on colluvial slopes above irrigated valley floors, especially on the older islands (Kurashima and Kirch 2011: 3667-68), and Kamakau (1976:33) describes taro plantings "on mountain slopes" in the 'apa 'a zone, but thus far it has not been possible to identify Hawaiian terms clearly linked to this potential ecotope, even though land claims appear to have been made on some of these slopes (Anderson 2001: 114-19; Maly and Maly 2002b). ${ }^{7}$

Several Hawaiian terms were found marking smaller-scale ecotopes where domesticates or wild species were grown or tended far from the lower-elevation ecotopes or densely cultivated field systems. For example, wild olona and domesticated 'awa grew best in moist upland soils, and the term olon $\bar{a}$ was applied polysemously to the higher-elevation patches where it was grown or tended. Bananas, commonly grown in lower-elevation $m \bar{a} l a$ and along rock walls or embankments in field systems or freshwater ponds, were also cultivated in ' $e$ ' $a$ mai' $a$ or ' $e$ ' $a$, called "mountain banana patches" (Kamakau 1976: 36; Pukui and Elbert 1986: 33) or "banana field" (Fornander 1919a, vol. 5: 598-99). One instance was found of this last ecotope being claimed in a nineteenth-century land record (LCA 5810, Kaopukauila, Maigret n.d.).

Concepts of contiguity and proximity also occurred in Hawaiian agricultural land nomenclature. Terms for edges, borders (lihi, nihi) and banks (kaikä, kapaha 'i, pae) occur regularly in nineteenth-century land claims and Boundary Commission testimonies and, in many instances, they are associated with domesticated plants. For instance, rock walls or piles (kuaiwi) paralleling the vertical mountain fall line within field systems, especially in Kona, were often planted with sugar cane, paper mulberry, sweet potato and ti. Taro pond embankments (kuakua, kuāuna) "were [also] kept under cultivation" in sugar cane, banana, ti and kava (Kamakau 1976: 41; Nakuina 1893: 83).

Concepts of temporality such as freshness or newness versus overuse, harvested or exhausted were also found in the customary agricultural lexicon, and in noun form their physical-biotic referents can be viewed as ecotopes. The Hawaiian terms kipahulu, mahakea and pahulu are defined as "place where soil is worn out", "once cultivated land", "over-farmed soil" and/or "fallow" (Pukui and Elbert 1986: 154, 218, 301). 'A 'ae is defined by these same authors (p. 2) as a "taro patch where the taro has been pulled up" (see also Fornander 1919b, vol. 6: 160), and Fornander defines kahili pulu [kāhili pulu] (p. 164) as a cleared sweet potato field. New taro patches are called hakupa' $a$ and their freshly packed embankments kuakuaku. A field readied for planting after burning (or recently turned) might be called makawela or wela (Handy and Handy 1972: 129; Kamakau 1976: 26, 33; Pukui and Elbert 1986: 50, 170, 228, 383). 


\section{The Freshwater Landscape: Terms and Concepts}

Malo does not describe freshwater environmental categories at length in his discussion (1903: 39) of broader-scale ecotopic belts. But streams cut perpendicularly across these belts, other natural water features (springs, seeps) were more or less randomly dispersed within them, and most of the freshwater ponds were constructed immediately behind or within the seashore belt or strand (kahakai) or in adjacent stream valleys mostly on the older islands. Permanent watercourses occur primarily on the windward ( $k$ o ' $\mathrm{olau}$ ) sides of the larger islands (except for Ni'ihau, Lana'i and Kaho'olawe) (Kikuchi 1973: 40-41), while intermittent streams, springs and seeps are located throughout the archipelago. Those in leeward (kona) settings were of particular importance to humans because of the rain-shadow effect common to the larger islands.

Over two dozen Hawaiian terms have been used to denote elements of freshwater hydrographic systems, such as natural streams, waterfalls and cascades, watercourse banks or edges, and headwaters and their mouths, as well as lakes, natural or man-made ponds, puddles, water sources or springs, freshets, hot springs and wetlands, marshes or swamps (Kamakau 1976: 10-11; Kepelino in Beckwith 2007; Pukui and Elbert 1986). As for other oceanic and terrestrial elements glossed by multiple terms, it is unclear at what level synonymy or island lexical variation occurred among these hydrographic terms, or whether some marked functional or conceptual differences. The relationship between freshwater and saltwater and their uses was complex, especially where the two types of water mingled to form brackish water, as at estuaries.

Hawaiians modified many aspects of natural freshwater systems for ease of access and use, bathing, irrigation and, in upland streams and lowland lakes and ponds, the exploitation of freshwater fisheries and other resources. Much of the earlier human effort in this domain was directed towards flatter near-shore areas and larger stream valleys where extensive taro ponds $\left(l o{ }^{\prime} i\right)$ and freshwater aquacultural ponds (loko $i^{\prime} a$ ) were created. In later periods, effort was extended to irrigated terraces in narrower upland gulches and to adjacent tablelands (McCoy and Graves 2010). Most were fed by freshwater ditches or canals ( 'auwai) that were drawn from natural streams or springs. While most of the humanised watercourses were short, some are known to have been several miles long (Kikuchi 1973: 64-65). Freshwater ponds drained to the sea via outlet canals.

Springs were sought by Hawaiians for drinking water, and thus collectively constituted a traditional ecotope in their own right. Natural and constructed ponds and their canals and enclosures, as well as lakes, streams and wetlands, were similarly defined by physical features, but also by biotic elements and the levels of human modification and management. Some natural streams were periodically blocked or diverted by dams into channels $(h \bar{a})$ (Fornander 1919a, vol. 5: 512; Kikuchi 1973: 64), permitting freshwater fish (Kahā'ulelio 2006: 211), probably mostly stream gobies ('o 'opu, including species of Awaous, Lentipes, and Sicyopterus) and freshwater shrimp ('opae, including 
species of Atyoida, and Macrobrachium) (Yamamoto and Tagawa 2000), to concentrate and be gathered, sometimes following incapacitation by plant poisons (Kikuchi 1973: 127; see Stokes 1921 for plants used). Some wetter upland Hawaiian ecotopes, as mentioned above, were associated with important plant resources like olona and 'awa.

Hawaiians modified or built hundreds of lowland ponds for taro production (lo ' $\mathrm{i}$ kalo) and for aquaculture (loko i'a) involving several fish species. For example, loko 'ama'ama were specifically designated for mullet (Mugil cephalus) or for both fish and taro (loko i'a kalo) (see Kikuchi 1973: 93, 116 for preferred species; see Kirch 1977 for an "etic" classification of $l o$ ' $i$ types). Species of edible algae are associated with freshwater ponds, as was a poorly known sort of edible mud (Kikuchi 1973: 94-95). Some freshwater ponds or sections of ponds $\left(\mathrm{ki}^{\prime} \mathrm{o}\right)$ were created specifically for fish spawn and fry (p. 57), and these ponds and others were sometimes equipped with stone piles $(u m u)$ where smaller fish could feed and hide from predators. Loko 'aka'akai ponds, cited in Māhele land claims, produced a wild but tended bulrush (Schoenoplectus lacustris) and probably makaloa (Cyperus laevigatus), both well-known thatching and weaving materials. Other sedges with economic value like kili 'o 'opu or mokae (possibly Cyperus spp. and/or Torulinium odoratum) were also found there. As we have seen, freshwater pond walls (kuāuna) were often planted with sugar cane, banana, kava and paper mulberry. According to Kamakau (1976: 33) marshlands (pohō) were planted with taro and constituted an "important ... kind of wet taro plantings". Apart from the benefits accrued by Hawaiian commoners in their exploitation of upland streams, substantiated by mid-nineteenth-century fishery rights claims (Maly and Maly 2003), evidence points to the chiefly religious classes as the principal motivators and beneficiaries of the man-made freshwater ecotopes (Kikuchi 1973: 51 citing Kamakau 1869: 180).

\section{Hawaiian Geographic-Topographic Terms, Concepts and Ecotopes}

Hawaiian geographic-topographic terms and concepts reflect an awareness of the archipelago (pae 'äina) within an oceanic expanse (the central Pacific Ocean) and an appreciation of the irregular nature of island landscapes resulting from volcanism and erosion. As we have seen, several geomorphological island types were recognised and named, as were passages or straits between islands. The central calderas and mountain ranges of several of the islands were noted for their high-elevation features, their effects on weather, the associated presence of wetter or drier zones, and their relationships with naturally occurring streams (kahawai), desert-like areas (wao one) and vegetational differences. Hawaiian terms refer to windward and leeward sides of each island and, as a result at least in part of the prevailing northeast trade winds that variously interact with island shapes and orientations, many distinct weather phenomena were recognised, with hundreds of terms and concepts for winds, clouds and types of precipitation. 
Similarly, the uphill-downhill directionality inherent in the often gently sloping island topographies, oriented from central mountains to seashore, was often marked either as "toward the uplands" (uka) or "toward the sea" (kai), depending on the physical location of the speaker, much as one finds elsewhere in the world (Meilleur 1985). Such terms and associated phrases like $k \bar{o}$ kula kai 'belonging to the lowlands' or ko kula uka 'belonging to the uplands', though not ecotopic categories, were undoubtedly applied in discussions involving travel, weather prediction and resource production or acquisition (Holland 1971: 28; Pukui and Elbert 1986).

At more specific spatial levels, the irregular physiognomic natures of the eight main islands resulting from approximately 5 million years of volcanism, sedimentation and terrestrial erosion (Kikuchi 1973: 36; Newman 1970), when combined with nearly a thousand years of exploitation by a growing human population (Schmitt 1968), contributed to Hawaiian recognition of many ecotopic patches that are primarily linked to topographic features. Terms and concepts (Kamakau 1976; Malo 1903; Pukui and Elbert 1986) range from the summits of the three major volcanoes (Mauna Kea and Mauna Loa on Hawai'i Island; Haleakalā on Maui) to large and small hills, valleys and gulches, ravines, ridges, peaks, caves/caverns, crevices, holes, plains and cliffs. Shoreline or strand features like seashore, tidal pools, sandy beach, sand dunes and capes are also lexically encoded in a manner that distinguishes size, shape, density, edges and ledges, depth and steepness, proximity to other features, and dominant associated plants or animals (e.g., kahaone pōhuehue 'beach with beach morning glory plants' [Ipomoea pes-caprae]) (Kamakau 1976: 11). The Hawaiian term for cliff (pali) possesses over a dozen binomial variants where the head term is followed by a descriptive modifier, and the term for hill $\left(p u^{\prime} u\right)$ has at least eight binomial variants for hill types. The orientation of a mountain might be distinguished by reference to its flanks - the front or the back (kaha alo, kaha kua) - depending on point of observation. Such geographic-topographic segregates and the qualitative aspects of directionality inherent in customary landscape conceptualisation (Malo 1903: 28-32), as also found in Hawaiian trail system nomenclature (ala hele, alaloa, many terms/phrases) (Kamakau 1976: 10; Malo 1903: 38; Maly 1999: 7), were used for spatial reckoning and way-finding and, more specifically, to help establish boundaries in the traditional political-economic system. Several are mentioned by the nineteenth-century Hawaiian writers as qualifying features of the broader-scale ecotopes described above, especially for the higher mountain belts.

\section{Hawaiian Geologic-Edaphic Terms, Concepts and Ecotopes}

In the absence of metal, Hawaiians focused on the harder rocks to fashion weapons, cutting tools, pounders and other domestic implements. At least 15 general-purpose terms were found that gloss to kinds of stone associated 
with these uses (Malo 1903: 40-41; Pukui and Elbert 1986). The cultural importance of the harder stones is reflected in some instances by their classification at four or more levels of inclusion: rock or stone (pōhaku), hard rock or stone (pōhaku pa 'a), and the many kinds of hard stone such as basalt ( 'alā), this last which can then be subdivided into several "kinds" of basalt, where separate terms are used (e.g., 'elek $\bar{u}$ 'coarse vesicular basalt') (Pukui and Elbert 1986: 40) or the head term 'alā is modified by a descriptive epithet (pp. 16-19). The same applies to several other kinds of rock that were used domestically or for building material, and for dirt or soil. At least 15 terms are used to denote softer stones like pumice ( 'ana) that were used as abraders and for polishing. At least 25 terms for stones used as fishing weights were found, and at least 10 terms refer to stone types used in making leisure activity items, such disks used in 'ulu maika, a Hawaiian bowling game. Similarly, many Hawaiian terms denote types of dirt or soil (lepo), including hard-baked (lepo pa'a), rocky/gravelly (makaili), sandy ('àone, lauone) or muddy areas (kelekele) of the landscape, as well as kinds of volcanic rock (especially ' $a$ ' $\bar{a}$ 'craggy lava' versus pāhoehoe 'smooth lava', and ākeke 'cinder' (Handy 1940: 4; Pukui and Elbert 1986). Lincoln et al. (2014) describe high spatial variability of soil types in Kona, Hawai'i Island as a function primarily of lava flow age and chemistry and precipitation, and several of these soil types are recognised within the Hawaiian lexicon.

In cases where substantial landscape patches were dominated by geologicedaphic features, whether used for referential or utilitarian purposes, they are recognisable as Hawaiian ecotopes. Some examples include dirt, mud, clay (pālolo); sand (one); pebbles (e.g., 'ili'ili, unu); rocky flat land (häpapa) or rutted ground (mālualua) (Kamakau 1976: 40); alluvial soil (lauone) preferred by farmers (Pukui and Elbert 1986: 197); and soils purposely created by decomposition of specific plant species such as pākukui 'candlewood-based soil' and pāpulupulu 'tree-fern-based soil' (Fornander 1919b, vol. 6: 160-62; Handy 1940: 51-52; Pukui and Elbert 1986: 306). Other soil types, such as 'alaea, defined as "water-soluble colloidal ocherous earth ... brick-red soil containing hematite" (Handy 1940: 4; Pukui and Elbert 1986: 17), were used for ritual or medicinal purposes. Many of these terms were applied polysemously to the specific resources and to the sites where they were concentrated, as for several of the biotically dominated ecotopes. For example, ' $a$ ' $\bar{a}$ is defined by Pukui and Elbert (p. 2) both as a type of lava and as an area "abounding with" this lava. In other cases, partial or full repetition of a head term for a soil type, like kele for mud and kelekele for where much mud occurred, was used to designate an ecotope where the geologic or edaphic feature was plentiful.

While many of the geologic-edaphic terms that denote ecotopes were primarily distinguished by their physical characteristics, several, as we have seen, also had biotic content, such as alluvial soil or soils formed primarily of decomposed vegetal matter, which were then planted with taro and other 
domesticates. The same is true for makaili, defined by Pukui and Elbert (1986: 226) as "rocky patches where sweet potatoes or taro were cultivated ... soil consisting of coarse sand, cinders, or gravel", and for mälualua 'rutted ground' that was planted with wauke (Kamakau 1976: 40).

Nevertheless, many of the Hawaiian terms associated with stones, rocks, dirt and soil have not yet been linked to geologic or edaphic segregates recognised by modern specialists: thus some may be synonyms, island variants, or descriptive phrases emphasising shape or color. Those terms that denote areas (lua 'eli pōhaku) where types of valuable stone were predictably found or quarried, where stones were used as boundary markers, or where kinds of useful soils were concentrated are most likely examples of customary Hawaiian ecotopes.

$$
* * *
$$

Using highly dispersed data from published and unpublished sources, some nearly 200 years old, and the recently proposed theoretical framework of Hunn and Meilleur (2010) as the analytical framework, it has been possible to reconstruct elements of customary Hawaiian classification of their oceanic and terrestrial environments in a manner that may have some cultural validity. Lexicalised Hawaiian ecotopes were shown to have existed at several levels of abstraction, with smaller-scale ecotopes generally distributed within broader-scale ones, and both appear to have been conceptualised as variable mixes of biotic, hydrographic, topographic, geographic, geologic, edaphic and anthropogenic elements. These ecotopes were variously linked by Hawaiians for practical purposes to plant and animal species and to physical elements and their use or acquisition, to a set of terms indicating directionality depending on context, and to a myriad of unique places marked by proper names.

High levels of agricultural and aquacultural production were attained by Hawaiians through substantial modification of natural landscapes and seascapes. The tokens of the anthropogenic ecotopes, along with those of the wild ecotopes, created a semantic and practical grid of real spaces and places. These were often conceptualised hierarchically, from where a range of oceanic and terrestrial resources were harvested, thereby sustaining a large Native Hawaiian population well into the nineteenth century.

Several ethnoecological patterns emerged from this study. Possibly the most notable was Hawaiians' classification of their oceanic and terrestrial space into over 30 broader-scale, general-purpose named ecotopes, often called belts in the historical literature, which progressively succeeded each other from the mountainous summits to the seashore and from there to the utmost bounds of the ocean. These categories were secondarily composed of smaller-scale, more special-purpose ecotopic patches, also named, that were more randomly distributed within the larger-scale ecotopes or belts, 
and whose semantic content was often more specifically definable. A third level of ethnoecological conceptualisation equates to the thousands of named places, each variably denoting a unique geographic space. Leaving the islands, their districts and the larger inhabited sites aside, the majority of the Hawaiian place names marked highly restricted areas, their uniqueness making these the most special-purpose of the Hawaiian landscape concepts. Combining these three ethnoecological domains into a complex referential system that overlaid their seascapes and landscapes permitted Hawaiians to predict resource presence and availability and to engage in fact-based communication and decision-making, all of which led to appropriate action, both planned and spontaneous, in suitable places.

\section{ACKNOWLEDGEMENTS}

An abbreviated version of this paper was presented at the Interdisciplinary Approaches to Landscape Representation colloquium, 24-25 February 2016, at the University of Amsterdam, The Netherlands. I am grateful to the organisers for the invitation to present at this meeting. I wish to thank MaryAnne Maigret, archaeologist at Pu'uhonua o Hōnaunau National Historical Park, for her work with me on an earlier project in which she researched Great Māhele land claims and related Boundary Commission testimonies; several of her discoveries are referenced in this paper. Partial funding for this research was provided by the late Sherwood and Lois Greenwell (Kealakekua Ranch Ltd.), to whom I express my sincere gratitude. Thanks to Eugene Hunn and Noa Lincoln for commenting on an earlier version of this paper, and to Melinda Allen for useful editorial suggestions.

\section{NOTES}

1. This portrait of Hawaiian colonisation is not accepted by all scholars (see Kirch 2010, 2011, 2014 for further details). Summaries of the most commonly proposed colonisation dates and scenarios are found in Allen (2014) and Lincoln and Vitousek (2017: 6).

2. Where terms in Hawaiian from original texts are spelled differently than modern renditions, these latter spellings, taken from the Hawaiian Dictionary (Pukui and Elbert 1986), follow in brackets.

3. Fathoms were converted to metres using the generally accepted equivalent of six feet or approximately two metres to a fathom. Nevertheless, in her translation of Kamakau's texts, in note 3, Pukui (in Kamakau 1976: 50-51) describes his use of the fathom (anana) in some contexts to mean about one metre and in other instances approximately two metres. In maritime matters she believed that Kamakau's fathom was equivalent to two metres. Nevertheless, she cites Kahā'ulelio's estimation of fishing zone depths (Kahā‘ulelio 2006: 43-45; Kamakau 1976: 90) as somewhat shallower than those proposed by Kamakau, though overlap exists between the two renditions. Fornander (1919b, vol. 6: 186) shows similar estimates. 
4. Malo's text was first published in Hawaiian in 1838 and translated into English in 1839. It was revised in 1858 and then retranslated and annotated by Emerson in 1898 [1903]. According to Emerson (1903: 11) in his "Biographical Sketch of David Malo", while working on his history of Kamehameha, Malo "made an extended visit to the island of Hawaii for the purpose of consulting the living authorities who were the repositories of the facts or eye-witnesses of the events to be recorded". While the timing of this visit and that of the preparation of his book Hawaiian Antiquities is unclear, it seems possible that some information in Chapter 7, "Natural and Artificial Divisions of the Land", may have been obtained during this visit, and it is possible that his terrestrial scheme may apply primarily to Hawai' $i$ Island and especially to its leeward side.

5. Meilleur (2010: 163) states, "The folk biotope is proposed ... as the basic folk ecological unit employed ... to cognize and order biotic space at a level more extensive than that of the individual folk botanical or zoological taxa." It is equivalent to a biotically dominated folk ecotope. To avoid confusion, I will continue to use ecotope throughout this paper.

6. A recent geospatial analysis of native vegetation by The Nature Conservancy of Hawai' $i$ (Gon et al. 2018) demonstrated that the pre-contact Hawaiian population substantially modified about 15 percent of the native terrestrial ecosystems, with the majority of changes occurring in the lowland dry and mesic vegetation zones. Since Euro-American contact, over 50 percent of native habitats has been lost.

7. On p. 112 Maly and Maly (2002b) cite a sweet potato patch claimed by Hanauapuaa "on the slope-he wahi pali uala [he wahi pali 'uala]" in the ahupua ' $a$ of Kuiaha, east Maui. They identify similar claims on other hillsides in east Maui ahupua 'a, not only for sweet potato cultivation but for paper mulberry, coconut, banana, screwpine and breadfruit. These claims are described as located near or on the cliff or cliff-side, in the gulch, etc. (pp. 116, 125-26).

\section{REFERENCES}

Allen, Melinda, 2001. Gardens of Lono: Archaeological Investigations at the Amy B.H. Greenwell Ethnobotanical Garden, Kealakekua, Hawaii. Honolulu: Bishop Museum Press.

2004. Bet-hedging strategies, agricultural change, and unpredictable environments: Historical development of dryland agriculture in Kona, Hawaii. Journal of Anthropological Archaeology 23: 196-224.

2014. Marquesan colonization chronologies and post-colonization interaction: Implications for Hawaiian origins and the "Marquesan homeland" hypothesis. Journal of Pacific Archaeology 5 (2): 1-17.

Allen, Melinda and Patricia McAnany, 1994. Environmental variability and traditional Hawaiian land use patterns: Manukā's cultural islands in seas of lava. Asian Perspectives 33 (1): 19-55.

Anderson, Pia-Kristina, 2001. Houses of the Kama'aina: Historical Anthropology in a Hawaiian Valley. PhD thesis, University of California, Berkeley.

Athens, J. Stephen, Timothy Rieth and Thomas Dye, 2014. A paleoenvironmental and archaeological model-based age estimate for the colonization of Hawai'i. American Antiquity 79 (1): 144-55. 
Barrère, Dorothy, 1976. Preface. In S. Kamakau, The Works of the People of Old: Na Hana a ka Po'e Kahiko. Honolulu: Bishop Museum Press, pp. v-vi.

Beckley, Emma, 1883. Hawaiian Fisheries and Methods of Fishing. Honolulu: Advertiser Press.

Beckwith, Martha, [1932] 2007. Kepelino’s Traditions of Hawaii. Honolulu: Bishop Museum Press.

Cobb, John, 1903. The commercial fisheries of the Hawaiian Islands. In D. Jordan and B. Evermann (eds), The Aquatic Resources of the Hawaiian Islands, Bulletin of the United States Fish Commission, Vol. 23, Part II. Washington: Government Printing Office, pp. 715-65.

Emerson, Nathaniel, [1898] 1903. Biographical sketch of David Malo. In D. Malo, Hawaiian Antiquities. Honolulu: Bishop Museum Press, pp. 5-14.

Field, Julie, Jacqueline Lipphardt and Patrick Kirch, 2016. Trends in marine foraging in precontact and historic leeward Kohala, Hawai'i Island. Pacific Science 70 (3): $287-307$.

Finney, Ben, 1959. Surfing in ancient Hawaii. Journal of the Polynesian Society 68 (4): $327-47$.

Fornander, Abraham, 1919a. Fornander Collection of Hawaiian Antiquities and Folk-lore. Edited by T.G. Thrum. Memoirs of the Bernice Pauahi Bishop Museum, Vol. V, Part III. Honolulu: Bishop Museum Press. -1919b. Fornander Collection of Hawaiian Antiquities and Folk-lore. Edited by T.G. Thrum. Memoirs of the Bernice Pauahi Bishop Museum ..., Vol. VI-Part I. Honolulu: Bishop Museum Press.

Gon, Samuel, Stephanie Tom and Ulalia Woodside, 2018. 'Āina Momona, Honua Au Loli-Productive lands, changing world: Using the Hawaiian footprint to inform biocultural restoration and future sustainability in Hawai'i. Sustainability 10: $1-21$.

Handy, E.S. Craighill, 1940. The Hawaiian Planter-Volume 1. Honolulu: Bishop Museum Press.

Handy, E.S. Craighill and Elizabeth Handy, 1972. Native Planters in Old Hawaii: Their Life, Lore, and Environment. Honolulu: Bishop Museum Press.

Handy, E.S. Craighill and Mary Kawena Pukui, 1958. The Polynesian Family System in Ka' 'u, Hawai ' $i$. Rutland, VT and Tokyo: Charles E. Tuttle Co.

Holland, Jerald, 1971. Land and Livelihood: The Kona Coast about 1825. MA thesis, University of Hawai'i, Honolulu.

Hunn, Eugene and Brien Meilleur, 2010. Toward a theory of landscape ethnoecological classification. In L. Johnson and E. Hunn (eds), Landscape Ethnoecology: Concepts of Biotic and Physical Space. Oxford and New York: Berghahn Books, pp. 15-26.

Johannes, Robert, 1981. Words of the Lagoon. Berkeley: University of California Press.

Kahā'ulelio, Daniel, [1902] 2006. Ka 'Oihana Lawai 'a: Hawaiian Fishing Traditions. Honolulu: Bishop Museum Press.

Kamakau, Samuel, [1869-70] 1976. The Works of the People of Old: Na Hana a ka Po'e Kahiko. Honolulu: Bishop Museum Press.

Kelly, Marion, 1983. Nā Māla O Kona: Gardens of Kona. Bishop Museum Departmental Report Series, report 83-2. Honolulu.

Kikuchi, William, 1973. Hawaiian Aquacultural System. PhD thesis, University of Arizona, Tucson. 


\section{Hawaiian Seascapes and Landscapes}

Kirch, Patrick, 1977. Valley agricultural systems in prehistoric Hawaii: An archaeological consideration. Asian Perspectives 20 (2): 246-80.

1985. Feathered Gods and Fishhooks. Honolulu: University of Hawai'i Press. 2010. Peopling of the Pacific: A holistic anthropological perspective. Annual Review of Anthropology 39: 131-48.

2011. When did the Polynesians settle Hawai'i? A review of 150 years of scholarly inquiry and a tentative answer. Hawaiian Archaeology 12: 3-26.

2014. The prehistory of Hawai'i. In E. Cochrane and T. Hunt (eds), The Oxford Handbook of Prehistoric Oceania. Oxford: Oxford University Press. Published online October 2014.

Kurashima, Natalie and Patrick Kirch, 2011. Geospatial modeling of pre-contact Hawaiian production systems on Moloka'i Island, Hawaiian Islands. Journal of Archaeological Science 38 (12): 3662-74.

Ladefoged, Thegn, Patrick Kirch, Samuel Gon, Oliver Chadwick, Anthony Hartshorn and Peter Vitousek, 2009. Opportunities and constraints for intensive agriculture in the Hawaiian archipelago prior to European contact. Journal of Archaeological Science 36 (10): 2374-83.

Ladefoged, Thegn, Alison Preston, Peter Vitousek, Oliver Chadwick, Julie Stein, Michael Graves and Noa Lincoln, 2018. Soil nutrients and pre-European contact agriculture in the leeward Kohala Field System, Island of Hawai'i. Archaeology in Oceania 53 (1): 28-40.

Lincoln, Noa, Oliver Chadwick and Peter Vitousek, 2014. Indicators of soil fertility and opportunities for precontact agriculture in Kona, Hawai'i. Ecosphere 5 (4): art. 42.

Lincoln, Noa and Thegn Ladefoged, 2014. Agroecology of pre-contact Hawaiian dryland farming: The spatial extent, yield and social impact of Hawaiian breadfruit groves in Kona, Hawai'i. Journal of Archaeological Science 49: 192-202.

Lincoln, Noa and Peter Vitousek, 2017. Indigenous Polynesian agriculture in Hawai'i. In Oxford Research Encyclopedia of Environmental Science. Oxford: Oxford University Press. Published online March 2017, pp. 1-43.

Maigret, MaryAnne, n.d., 2013. Unpublished field notes.

Major, Maurice, 2001. An agricultural history of Kealakekua. In M. Allen (ed.), Gardens of Lono. Honolulu: Bishop Museum Press, pp. 23-46.

Malo, David, [1898] 1903. Hawaiian Antiquities. Honolulu: Bishop Museum Press.

Maly, Kepā, 1999. Nā ala hele ma Kai O Kohala Hema-The Coastal Trails of South Kohala. Unpublished report HiAla-17k (043099), Kumu Pono Associates.

Maly, Kepā and Onaona Maly, 2001. He Wahi Mo 'olelo No Nā 'Āina, A Me Nā Ala Hele $i$ Hehi ' $\mathrm{Ia}$-A Historical Overview of the Lands, and Trails Traveled, Between Keauhou and Kealakekua, Kona, Hawai'i. Unpublished report HiAla40061501, Kumu Pono Associates.

2002a. Kīpāhoehoe Ma Kapalilua-Kona Hema, Hawai 'i-A Cultural Study of Kīpāhoehoe and Neighboring Lands in Kapalilua, South Kona, Island of Hawai'i. Unpublished report HiKipa70-070502, Appendix D, Kumu Pono Associates. 2002b. Wai o ke ola: he wahi mo 'olelo no Maui Hikina-A Collection of Native Traditions and Historical Accounts of the Lands of Hāmākua Poko, Hāmākua Loa and Ko'olau, Maui Hikina (East Maui), Island of Maui. Unpublished report MaHikina 59-011702b, Vol. 1, Kumu Pono Associates. 
2003. Ka Hana Lawai 'a A Me Nā Ko 'a O Na Kai 'Ewelu-A History of Fishing Practices and Marine Fisheries of the Hawaiian Islands. Unpublished report HiPae74 (080103), Kumu Pono Associates.

2005a. He Mo'olelo 'Āina No Ka'eo-A Cultural-Historical Study of Ka'eo and Other Lands in Honua'ula, Island of Maui. Unpublished report MaKaeo110 (122705a), Kumu Pono Associates.

2005b. Mauna Kea-Ka Piko Kaulana O Ka 'Aina-Mauna Kea, the Famous Summit of the Land. Unpublished study HiMK67-OMKM (033005b), Kumu Pono Associates.

-2006. Hilo Paliku- - Hilo of the Upright Cliffs. Unpublished study HiHETF116Laupahoehoe (120506a), Kumu Pono Associates.

-2012. He Mo 'olelo 'Aina-Traditions and Storied Places in the District of 'Ewa and Moanalua (in the District of Kona), Island of O'ahu. Unpublished study 131, Kumu Pono Associates, pp. 504-720.

Manu, Moke and others, [1992] 2006. Hawaiian Fishing Traditions. Honolulu: Kalamakū Press (University of Hawai'i Press).

McCoy, Mark and Michael Graves, 2010. The role of agricultural innovation on Pacific Islands: A case study from Hawai'i Island. World Archaeology 42 (1): 90-107.

McEldowney, Holly, 1983. A description of major vegetation patterns in the WaimeaKawaihae region during the early historic period. In J. Clark and P. Kirch (eds), Archaeological Investigations of the Mudlane-Waimea-Kawaihae Road Corridor, Island of Hawai ' $i$ : An Interdisciplinary Study of an Environmental Transect. Department of Anthropology Report 83-1. Honolulu: Bishop Museum Press, pp. $407-48$.

McIvor, Isaac and Thegn Ladefoged, 2018. Intermittent irrigation in the Waimea Field System, Hawai'i Island: A computational fluid dynamics model. Journal of Archaeological Science: Reports 17: 335-45.

Meilleur, Brien, 1985. Gens de montagne, plantes et saisons: Termignon en Vanoise. Le Monde Alpin et Rhodanien 1: 1-79.

2010. The structure and role of folk ecological knowledge in Les Allues (Savoie), France. In L.M. Johnson and E.S. Hunn (eds), Landscape Ethnoecology: Concepts of Biotic and Physical Space. Oxford and New York: Berghahn Books, pp. 159-74.

Meilleur, Brien, Richard Jones, C. Alan Titchenal and Alvin Huang, 2004. Hawaiian Breadfruit: Ethnobotany, Nutrition, and Human Ecology. Honolulu: CTAHR, University of Hawai'i at Mānoa.

Mueller-Dombois, Dieter, 2007. The Hawaiian ahupua' $a$ land use system: Its biological resource zones and the challenge of silvicultural restoration. In N. Evenhuis and J. Fitzsimons (eds), Biology of Hawaiian Streams and Estuaries. Bishop Museum Bulletin in Cultural and Environmental Studies 3, pp. 23-33.

Nakuina, Emma, 1893. Ancient Hawaiian water rights and some of the customs pertaining to them. In T. Thrum (ed.), Hawaiian Almanac and Annual for 1892. Honolulu: Press Publishing Company, pp. 79-84.

Newman, T. Stell, 1970. Hawaiian Fishing and Farming on the Island of Hawaii in A.D. 1778. Honolulu: Division of State Parks.

-1971. Hawaii Island agricultural zones, circa A.D. 1823: An ethnohistorical study. Ethnohistory 18 (4): 335-51. 
Nordhoff, Charles, 1930. Notes on the off-shore fishing of the Society Islands. Journal of the Polynesian Society 39 (154): 137-73.

Pukui, Mary Kawena and Samuel Elbert, [1957] 1986. Hawaiian Dictionary. Honolulu: University of Hawai'i Press.

Pukui, Mary Kawena, Samuel Elbert and Esther Mookini, 1974. Place Names of Hawaii. Honolulu: University of Hawai'i Press.

Schmitt, Robert, 1968. Demographic Statistics of Hawaii: 1778-1965. Honolulu: University of Hawai'i Press.

Stokes, John, 1921. Fish-poisoning in the Hawaiian Islands. Occasional Papers of the Bernice Pauahi Bishop Museum, Vol. VII, No. 10: 219-33.

Titcomb, Margaret, 1972. Native Use of Fish in Hawaii. Honolulu: University of Hawai'i Press.

Vitousek, Peter, Thegn Ladefoged, Patrick Kirch, Anthony Hartshorn, Michael Graves, Sara Hotchkiss, Shripad Tuljapurkar and Oliver Chadwick, 2004. Soils, agriculture, and society in precontact Hawai'i. Science 304 (5677): 1665-69.

Wagner, Warren, Darrel Herbst and S.H. Sohmer, 1990. Manual of the Flowering Plants of Hawai ' $i$. Honolulu: Bishop Museum and University of Hawai' $i$ Press, 2 vols.

Yamamoto, Mike and Annette Tagawa, 2000. Hawai ' $i$ 's Native and Exotic Freshwater Animals. Honolulu: Mutual Publishing.

\section{AUTHOR CONTACT DETAILS}

Brien A. Meilleur, UMR 7206 Éco-anthropologie, Musée de 1'Homme, Muséum national d'Histoire naturelle, 17 place du Trocadéro, 75016 Paris, France. Email: brienmeilleur@aol.com 